\title{
THE LICHEN GENUS USNEA ON QUERCUS SUBER IN IBERIAN CORK-OAK FORESTS
}

\author{
Simón FOS ${ }^{\star}$ and Philippe CLERC $\ddagger$
}

\begin{abstract}
Fifteen species of Usnea are recorded from Iberian cork-oak forests: $U$. ceratina, $U$. cornuta, $U$. dasaea, $U$. esperantiana, $U$. flammea, $U$. fulvoreagens, $U$. glabrata, $U$. hirta, U. mutabilis, $U$. rubicunda, U. subcormuta, U. subfloridana, $U$. subscabrosa, $U$. substerilis and $U$. wasmuthii. A key for these species is provided. Details of morphology, chemistry, distribution, ecology and taxonomy are discussed. Usnea dasaea is reported as new to the Iberian Peninsula. New chemotypes of $U$. fulvoreagens (with squamatic acid) and $U$. wasmuthii (with psoromic acid) have been identified. Distribution maps of $U$. dasaea and $U$. subcornuta in Europe are presented. A new combination, Usnea subfloridana subsp. praetervisa (Asahina) P. Clerc, is proposed.

C 2000 The British Lichen Society
\end{abstract}

\section{Introduction}

Recently, several studies have focused on the systematics of European species of Usnea (Clerc 1984a, b, 1987a, b, c, 1991, 1992, 1994, 1997, 1998; Myllys 1994; Halonen \& Puolasmaa, 1995; Halonen 1997) and have provided valuable information on this difficult genus of fruticose lichens, so that accurate identification of especially SW European species is now possible. Usnea species are frequent and abundant in cork-oak forests on Quercus suber, where they attain a high degree of coverage on branches and a scattered growth on boles. The lack of updated studies on the systematics, floristic and ecology of the genus Usnea in Spain prompted us to focus on this genus.

Quercus suber is a Western Mediterranean endemic, distributed both in Europe and North Africa. It occurs preferentially in siliceous areas with a warm Mediterranean climate with oceanic influence. Its distributional area covers a total of $2.35 \mathrm{M} \mathrm{Ha}$, of which about $1.18 \mathrm{M} \mathrm{Ha}$ are found in Spain and Portugal (Montoya 1988). Cork-oak forests are mainly distributed in the south-west of the Iberian Peninsula, although scattered localities are numerous, including the Catalonian (Barcelona and Girona) and Valencian (Valencia and Castellón) areas. The cork oak can be found in several biogeographic provinces, in the thermo- and mesomediterranean vegetation belts with dry to hyperhumid ombroclimates (terminology of bioclimatic zones follows Rivas-Martínez 1987). This biogeographical and bioclimatological

\footnotetext{
*Institut 'Cavanilles' de Biodiversitat i Biologia Evolutiva, Facultat de Ciències Biològiques, Universitat de València, Dr. Moliner 50, 46100-Burjassot, Valencia, Spain.

‡Conservatoire et jardin botaniques de la Ville de Genève, $1 \mathrm{ch}$. de l'lmpératrice, case postale 60, CH-1292 Chambésy/GE, Switzerland.
} 
heterogeneity has allowed the differentiation of several vegetation series (Rivas-Martínez 1987; Rivas-Martínez et al. 1990).

In general Iberian evergreen sclerophyllous forests are basically dominated by $Q$. suber, which may be accompanied by other trees such as $Q$. canariensis, $Q$. faginea, $Q$. rotundifolia, Pinus pinaster, etc. and bushes such as Arbutus unedo, Phillyrea angustifolia, P. latifolia, Viburnum tinus, Erica arborea, etc. Since cork harvesting is an important economic resource, the landscape of the cork-oak territories is deeply influenced by forestry practices such as understory removal or forest opening. The outcome is that cork-oak forests show very different structures ranging from dense stands, mostly in Cádiz and Catalonia, to grass-woodlands in the Extremadura plains.

The aim of the present study is to give a comprehensive account of the Usnea species occurring on $Q$. suber in the Iberian cork-oak forests. It adds one species to the lichen flora of the Iberian Peninsula and presents the European distribution of two poorly understood species. Furthermore, short morphological descriptions, chemical information, including new chemotypes of $U$. fulvoreagens and $U$. wasmuthii, and a key for the species studied are provided.

\section{Materials and Methods}

The material studied has been collected in different cork-oak forests of the Iberian Peninsula (Fig. 1). A list of the localities studied, with vegetation series, elevation and UTM co-ordinates, is provided below. Throughout the text bold numbers are used to identify the different sites.

A. Mesomediterranean subhumid series of cork oak in NE Spain: Carici depressae-Querco suberis sigmetum.

1. Girona, Agullana, Pla de Pujalts, $300 \mathrm{~m}, 31$ TDG8594. 2. Girona, Begur, Sa Tuna, $250 \mathrm{~m}$, 31TEG1845. 3. Girona, Sant Sadurni, Puig dels Cristians, 350 m, 31TDG9239. 4. Girona, Castell d'Aro, Santa Cristina d'Aro, Les Taules, $140 \mathrm{~m}, 31$ TEG0129. 5. Girona, Castell d'Aro, La Coma, $40 \mathrm{~m}, 31$ TEG0229. 6. Girona, Caldes de Malavella, Riera de Reclà, $120 \mathrm{~m}$, 31TDG8627. 7. Girona, Caldes de Malavella, Llagostera-Caldes de Malavella road, $100 \mathrm{~m}$, 31TDG8831. 8. Girona, Lloret de Mar, Los Pinares, $180 \mathrm{~m}, 31$ TDG8520. 9. Barcelona, San Celoni, Torrent de Olzinelles, $220 \mathrm{~m}, 31$ TDG5814. 10. Barcelona, Fogàs de Monclús, La Costa-Mosqueroles road, $580 \mathrm{~m}, 31$ TDG5121. 11. Girona, Santa Coloma de Farnés, Serrat del Corb, $260 \mathrm{~m}, 31 \mathrm{TDG} 6736$.

B. Meso-thermomediterranean subhumid series of cork oak in E Spain: Asplenio onopteridisQuerco suberis sigmetum.

12. Castellón, Alcudia de Veo, Benitandús artificial lake, $350 \mathrm{~m}, 30 \mathrm{SYK} 2724$. 13. Castellón, Algimia de Almonacid, Bco. de Agua Negra, 800 m, 30SYK2320. 14. Castellón, Ahín, Los Noguerales, 725 m, 30SYK2718. 15. Castellón, Azuebar, Mosquera, 700 m, 30SYK2517.

C1. Meso-thermomediterranean humid-hyperhumid series of cork oak in SW Spain: Teucrio baetici-Querco suberis sigmetum.

16. Cádiz, Grazalema, Cerro del Montón, $1100 \mathrm{~m}, 29 \mathrm{STF} 8574$. 17. Málaga, Cortes de la Frontera, Cerro del Alcornocal, $870 \mathrm{~m}$, 30STF8354. 18. Cádiz, Jimena de la Frontera, Between Jimena de la Frontera and La Sauceda, $220 \mathrm{~m}, 30 S T F 7540$. 19. Cádiz, Jerez de la

Frontera, Puerto Galiz, $440 \mathrm{~m}, 30 \mathrm{STF} 6748$. 20. Cádiz, Alcalá de los Gazules, Cerro de las Beatas, 280 m, 30STF6144. 21. Cádiz, Los Barrios, El Mojón, 140 m, 30STF6713. 23. Cádiz, Jerez de la Frontera, Loma de la Mesa, 360 m, 30STF6347.

C2. Thermomediterranean subhumid series of cork oak in SW Spain: Myrto communis-Querco suberis sigmetum.

22. Cádiz, Tarifa, Puerto del Bujeo, $460 \mathrm{~m}, 30 S T E 7195$. 23. Cádiz, Tarifa, El Tiradero, $200 \mathrm{~m}, 30 \mathrm{STF} 6705$.

38. PORTUGAI, Algarve, Cao, Serra do Espinhaço, 160 m. 39. Baixo Alentejo, Odemira, Fonte Soude, $175 \mathrm{~m}$. 

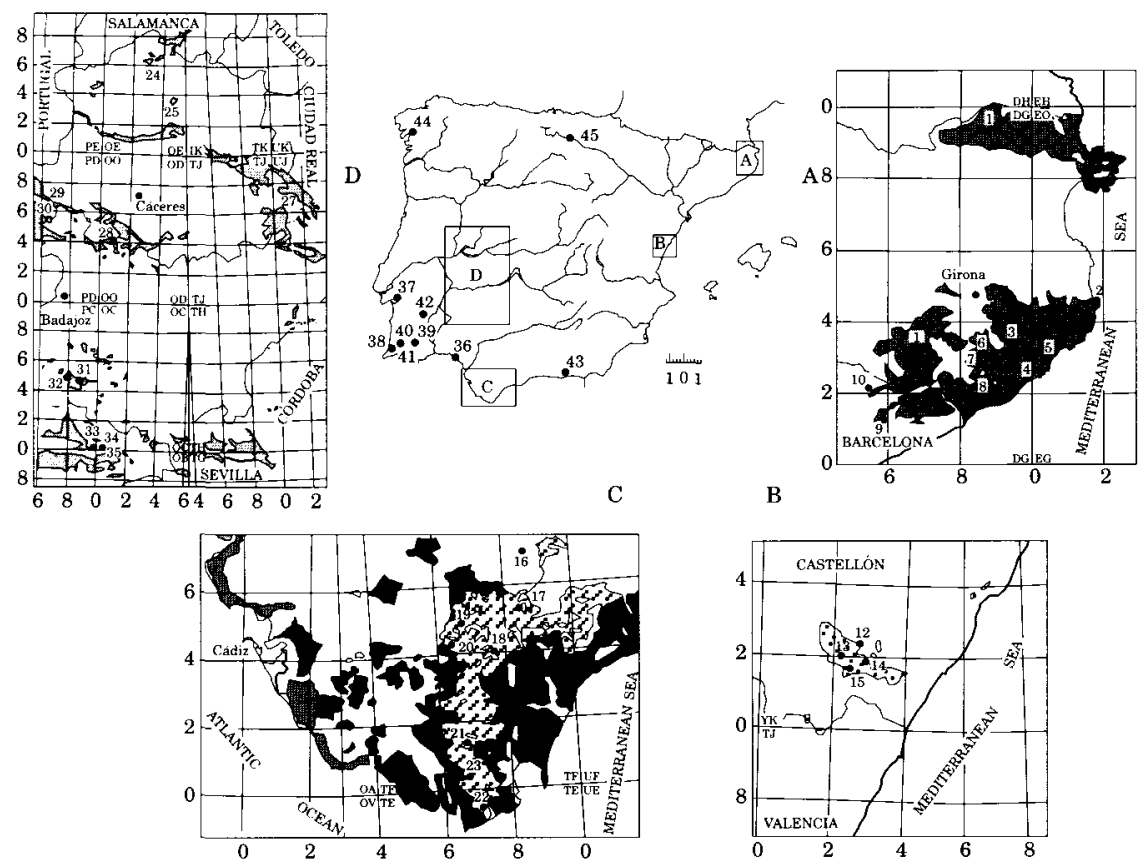

FIG. 1. Potential areas of Iberian cork-oak forests (dotted areas; according to Rivas-Martínez 1987) and location of the localities studied. A, Catalonia (Carici-Querco suberis S.); B, ValenciaCastellón (Asplenio-Querco suberis S.); C, Cádiz-Málaga [1, Teucrio-Querco suberis $S$. (oblique lines); 2, Myrto-Querco suberis $S$. (dark grey); 3, Oleo-Querco suberis $S$. (pale grey)]; D, Extremadura (Sanguisorbo-Querco suberis $S$.).

C3. Thermomediterranean dry-subhumid-humid series of cork-oak in SW Spain: Oleo sylvestrisQuerco suberis sigmetum.

36. Huelva, Almonte, Cerro Burraco, $50 \mathrm{~m}, 29 S Q B 0616$. 37. PORTUGAL, Ribatejo, Between Aguas de Moura and Setubal, $30 \mathrm{~m}$.

D. Mesomediterranean subhumid-humid series of cork oak in C to W Spain: Sanguisorbo agrimonioidis-Querco suberis sigmetum.

24. Cáceres, Casar de Palomero, El Pasil, $490 \mathrm{~m}$, 29TQE3464. 25. Cáceres, Plasencia, $380 \mathrm{~m}, 29 \mathrm{TQE} 4935.26$. Cáceres, Castañar de Ibor, Sierra de Porrinas, $700 \mathrm{~m}, 30$ STJ9287. 27. Cáceres, Alia, Vega del Guadarranquejo, $470 \mathrm{~m}, 30$ SUJ1772. 28. Cáceres, Cáceres, Dehesa de Calabazas, $380 \mathrm{~m}$, 29SQD1045. 29. Badajoz, S. Vicente de Alcántara, Puerto de Elice, $590 \mathrm{~m}, 29$ SPD6966. 30. Badajoz, S. Vicente de Alcántara, La Venta, $530 \mathrm{~m}, 29$ SPD6368. 31. Badajoz, Jerez de los Caballeros, Higuera de Vargas road, $440 \mathrm{~m}, 29 S P C 8847$. 32. Badajoz, Jerez de los Caballeros, Zahinos-Higuera de Vargas road, $300 \mathrm{~m}, 29 S P C 7746$. 33. Huelva, La Nava, Sierra de la Mesa, $480 \mathrm{~m}$, 29SPC9902. 34. Huelva, Galaroza, Sierra Navahermosa, $680 \mathrm{~m}, 29$ SQC0400. 35. Huelva, Marines, Sierra de San Ginés, $760 \mathrm{~m}, 29 S Q B 0897$.

40. PORTUGAL, Algarve, Serra de Monchique, Between Monchique and Aljerce, 450 m. 41. Algarve, Serra do Caldeirao, Bco. do Velho, $250 \mathrm{~m}$. 42. Alto Alentejo, Portel, Serra do Mendro, $310 \mathrm{~m}$.

Other vegetation series.

43. Granada, Polopós, Haza del Lino, Sierra de la Contraviesa, $1300 \mathrm{~m}$, 30SVF7174. 44. Pontevedra, Coto de Couso. Ulla river, $50 \mathrm{~m}, 29 \mathrm{TNH} 33$. 45. Burgos, Bozoo, Monte Recuenco, 850 m, 30TVN9131. 
Murolic acid aggr.

Bourgeanic acid (Bo)

Lobaric acid (Lo)

H

2'-O-Demethylpsoromic acid (2OP)

Psoromic acid (Ps)

Galbinic acid (Ga)

Salazinic acid (Sa)

Menegazziaic acid (Me)

Cryptostictic acid (Cr)

Constictic acid (CSr)

Stictic acid (Sr)

Connorstictic acid (CNr)

Norstictic acid (Nr)

Protocetraric acid (Pr)

Fumarprotocetraric acid (Fu)

Thamnolic acid (Th)

Squamatic acid (Sq)

Diffractaic acid (Df)

4-O-Demethylbarbatic (4OB)

Barbatic acid (Ba)

Atranorin (Ar)




Solvent A (TDA)

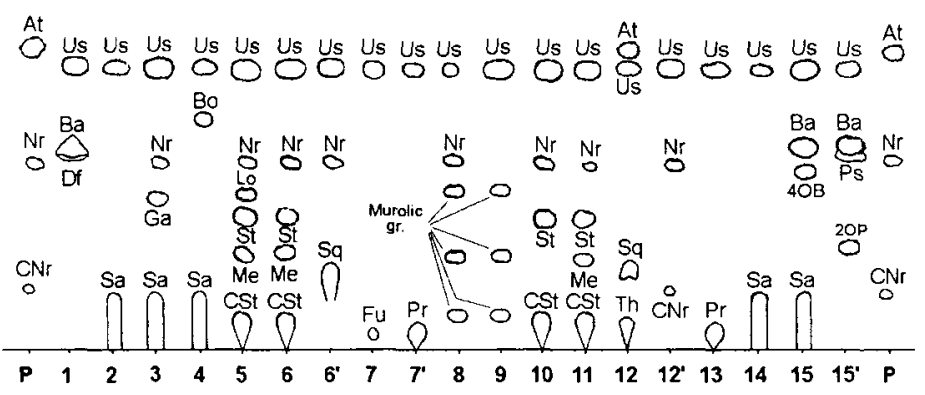

Solvent B (HEF)

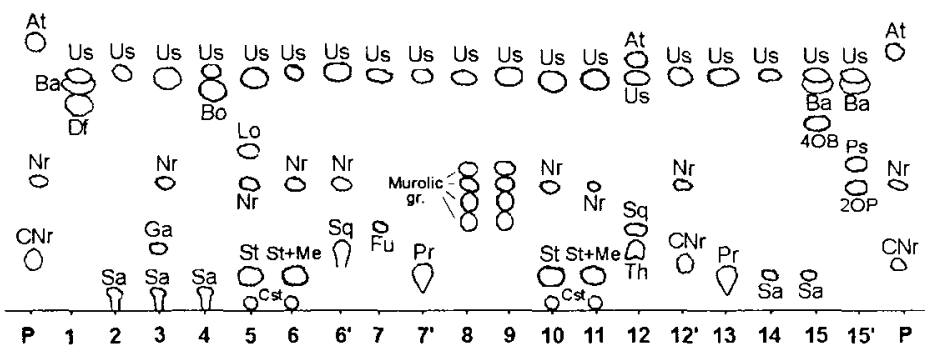

Solvent C (TA)

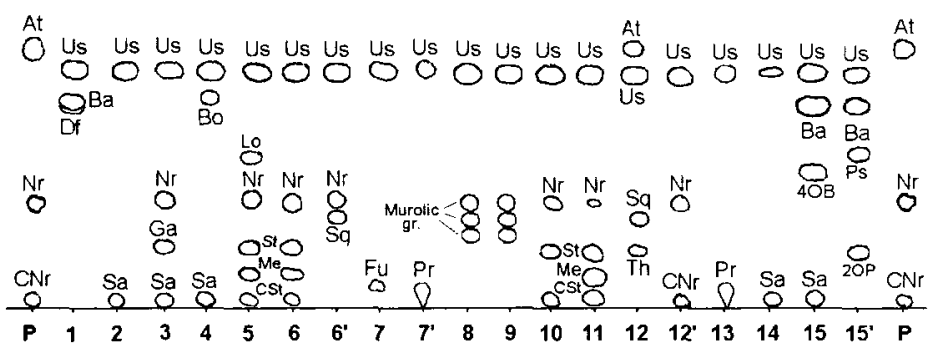

FIG. 2. Chromatograms of the species of Usnea studied in relation to the standard control and solvent system A (TDA), B (HEF) and C (TA) after acid spraying and heating (Culberson \& Ammann 1979). Abbreviations of the substances as in Table 1. Species: $\mathbf{P}=$ control of Parmelia acetabulum and Platismatia glauca; $1=U$. ceratina; $2=U$. cornuta; $3=U$. dasaea; $4=U$. esperantiana; $5=U$. flammea; $6=U$. fulvoreagens; $6^{\prime}=U$. fulvoreagens chemorace with squamatic acid; $7=U$. glabrata; $7^{\prime}=U$. glabrata with protocetraric acid only; $8=U$. hirta; $9=U$. mutabilis; $10=U$. rubicunda $; 11=U$. subcornuta $; 12=U$. subfloridana $; 12^{\prime}=U$. subfloridana subsp. praetervisa; $13=U$. subscabrosa; $14=U$. substerilis; $15=U$. wasmuthit; $15^{\prime}=U$. wasmuthii with psoromic acid. 
Most of the material has been examined by thin-layer chromatography (TLC) using the techniques described by Culberson \& Kristinsson (1970), taking into account the late modifications of Culberson (1972, 1974) and White \& James (1985) (first author) and Culberson \& Ammann (1979) (second author). Rf classes are given according to the solvents A/B/C. The main lichen substances are listed in Table 1 . The appearances of the spots on the TLC plates are compared in Fig. 2. Spot tests were performed with conventional tests (Clerc 1984a); unless otherwise stated, they were performed on the medulla of a branch of the middle part of the thallus, longitudinally cut with a razor blade.

Most old records of Usnea species are unreliable and thus information about geographical distribution in Spain is mainly based on specimens examined by ourselves. Literature records published after 1990, when several of the systematics studies of European species provided enough information for accurate identification, have been also included and are marked with an asterisk $(\star)$ although these specimens were not seen by ourselves.

Reference collections have been deposited in the VAB-Lich. Herbarium (Facultat de Ciències Biològiques. Universitat de València. Spain).

The second author is primarily responsible for the taxonomy, whereas all collecting and field observations were made by the first author. Both authors contributed to chemical studies.

\section{Key to the Species}

Young, necrotic or abnormal specimens with badly developed characters or growing in extreme localities are difficult to identify. Thus, the chemistry should be investigated with TLC and a specialist should preferably be consulted.

1 Thallus with a red, purple-red or pink pigment in the cortex (sometimes present only in the older parts of the thallus) or in the medulla (sometimes subcortical) . . . . . . . . . . . 2

Thallus without such a pigment (the medulla might be sometimes tinted orange close to the central axis) ......... 5

2(1) Pigment in the cortex .......... 10. U. rubicunda Pigment in the medulla ............. . . 3

3(2) Pigment subcortical, limited to a thin layer adjacent to the cortex .................. 11. U. subcornuta

Pigment \pm in the whole medulla, not limited to a thin layer adjacent to the cortex . . . . . . . . . . . . . . . 4

4(3) Medulla CK+ yellow-orange (diffractaic and barbatic acids); soralia at the top of raised tubercles ......... . . U. ceratina

Medulla CK - (fatty acids of the murolic acid group); soralia flat or slightly tubercular . . . . . . . . . 9. U. mutabilis

5(1) Medulla PD+ rust-red and $\mathrm{K}-$ (protocetraric acid as main substance) ..................... . . . . . . . . . .

Medulla $\mathrm{PD}-$ and $\mathrm{K}-$ or $\mathrm{PD}+$ and $\mathrm{K}+$ ( \pm protocetraric acid as accessory substance) $\ldots \ldots \ldots \ldots$

6(5) Lateral branches constricted at point of attachment; cortex thin (3-5\%); soralia conspicuous, excavate to irregularly efflorescentexcrescent, usually exceeding half width of branches, without isidiomorphs . . . . . . . . . . . 7. U. glabrata 
Lateral branches not constricted at point of attachment; cortex thick (8-15\%); soralia small, punctiform, superficial, smaller than half width of branches, with fragile isidiomorphs when young

13. U. subscabrosa

7(5) Lateral branches constricted at point of attachment, or \pm fusiform

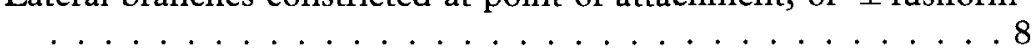

Lateral branches not constricted at point of attachment, never

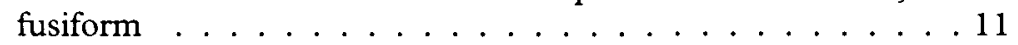

8(7) Fibrils short and spinulose, densely but \pm irregularly covering restricted parts (rarely the entire length) of branches; galbinic acid present .................... U. dasaea

Fibrils usually longer and slender, scattered on whole thallus; galbinic acid absent . . . . . . . . . . . . . 9

9(8) Soralia without isidiomorphs, large, more than half width of branches; terminal branches often twisted and contorted, resembling skeletal fingers; bourgeanic acid present

4. U. esperantiana

Soralia with isidiomorphs, large or small, punctiform; terminal branches usually not twisted; bourgeanic acid absent . . . 10

10(9) Cortex mat, never glossy; basal part pale, whitish to brownish, with numerous and conspicuous annulations; soralia usually large, more than half width of branches; salazinic acid never present

5. U. flammea

Cortex glossy; basal part brownish to jet black, with few and thin annulations; soralia punctiform but often becoming confluent and thus looking like a single large soralium; salazinic acid sometimes present . . . . . . . . . . . 2. U. cornuta

11(7) Mature soralia usually punctiform, smaller than half width of branches (large in some rare morphotypes of $U$. subfloridana), usually covered with isidiomorphs . . . . . . . . . . 12

Mature soralia usually large, isidiomorphs absent or present . . 13

12(11) Basal part pale, never jet black; main branches \pm angular, ridged, with depressions; papillae absent; norstictic acid or fatty acid of the murolic acid aggr. . . . . . . . . . . . . 8. U. hirta

Basal part jet black; main branches terete; papillae present; thamnolic acid \pm squamatic acid . . . . . . 12. U. subfloridana

13(11) Branches mostly anisotomic-dichotomous (best seen on terminal branches), uneven in thickness, \pm swollen, often sinuous; usnic or salazinic \pm barbatic acid . . . . . . . 15. U. substerilis

Branches mostly isotomic-dichotomous, tapering, not swollen, rarely sinuous ...................... 14

14(13) Basal part pale, whitish to brownish, with conspicuous annulations; mature soralia usually with numerous isidiomorphs; stictic acid aggr., norstictic acid ... . . . . . . . 5. U. flammea 
Basal part jet black, annulated or not; mature soralia usually with few or without isidiomorphs . . . . . . . . . . 15

15(14) Soralia deeply excavate, reaching central axis, not longitudinally stretched when mature, without isidiomorphs; basal part without small longitudinal cracks (at $50 \times$ magnification); stictic acid aggr., norstictic and \pm diffractaic acids . . . . 6. U. fulvoreagens Soralia flat to slightly excavate, usually not reaching central axis, longitudinally stretched when mature, isidiomorphs present (mostly on young soralia in protected parts of the thallus); \pm salazinic, \pm barbatic, \pm psoromic acids or thamnolic \pm squamatic acids . . . . . . . . . . . . 15. U. wasmuthii

\section{The Species}

\section{Usnea ceratina Ach.}

Lich. Univ.: 610 (1810).

Taxonomy. A detailed description is given in Halonen et al. (1998) and Herrera-Campos et al. (1998). The most characteristic features are the pendulous (shrubby when young or in suboptimal conditions), coarse and rigid thallus, the pinkish pigment in the medulla, the hard and vitreous cortex, the conspicuous tubercles that might become sorediate on top, and the $\mathrm{CK}+$ yellow-orange reaction of the medulla (diffractaic and barbatic acids).

Ecology and distribution. Corticolous, usually on branches in areas with common and persistent fog; rarely saxicolous (Rowe \& Egea 1986). It also grows on trunks of acid-barked old trees in relict woodlands, in well-lit sites or thin tree canopies. This species has a wide distribution in boreal and temperate regions of the Northern Hemisphere (James et al. 1992; Nimis 1993). In the Iberian Peninsula, it has been reported several times from northern Spain (Etayo 1989, 1990; Bahillo \& Carballal 1991; Terrón et al. 1992^).

It is quite rare in the Iberian cork-oak forests, being restricted to some humid and Atlantic cork-oak forests of southern $(17,21)$ and north-eastern Spain (7) and central Portugal (37). At these stands the biomass of other Usnea species such as $U$. rubicunda, $U$. subscabrosa or $U$. subcornuta is also high, especially on branches. Thalli of $U$. ceratina can exceed one metre in length in favourable sites (Bahillo 1989; Etayo 1989; James et al. 1992); specimens studied are usually no longer than $20 \mathrm{~cm}$.

Specimens examined. Spain: Andalucia: 17, 1993, E. Calvo, VAB-Lich. 4664; 21, 1992, S. Fos, VAB-Lich. 4537. Catalonia: 7, 1991, S. Fos, VAB-Lich. 4541.-Portugal: Ribatejo: 37, 1990, E. Barreno \&o S. Fos, VAB-Lich. 4578.

\section{Usnea cornuta Körb.}

Parerga Lichenol.: 2 (1865).

Taxonomy. Usnea cornuta s. str. is distinguished by the short, erect, tufted thallus, the lateral branches that are distinctly constricted at their point of 
attachment, the minute and numerous soralia, usually with abundant isidiomorphs, the thin (4-7\%) and glossy cortex and by its chemistry. In Europe, three morphologically indistinguishable chemical strains have been described (Clerc 1987a). The secondary chemistry in Iberian cork-oak forest seems to be fairly uniform (Table 1; Fig. 2): all specimens tested by TLC contained usnic and salazinic acids.

Ecology and distribution. This euoceanic species in the sense of Degelius (1935) grows on wood, bark or rocks, usually in well-lit open situations. It is more frequent on branches, although it also occurs on the boles of numerous phorophytes. This species is limited to extremely oceanic parts of West Europe, with some rare Mediterranean localities, ranging from SW Norway to Portugal (Clerc 1987a; Jørgensen 1996), although it is more frequent in western Europe (Nimis 1993). In Spain, it has been reported mainly from the north, in the Eurosiberian region.

In our survey, it has only been found in the southern limit of the Badajoz province (32) and in Catalonia (8), on boles of peripheral trees. These records are especially interesting, because $U$. cornuta has a strong preference for the Atlantic areas and is rare in Mediterranean territories. These two areas have a suboceanic climate, as evidenced by the richness and biomass of several Usnea species (U. flammea, U. rubicunda, U. subscabrosa, U. wasmuthii) and of several other oceanic-suboceanic lichens. We have also studied one specimen collected in Pontevedra by Barreno et al. in the NE of Spain (44).

Specimens examined. Spain: Catalonia: 8, 1991, S. Fos, VAB-Lich. 4633. Extremadura: 32, 1992, S. Fos, VAB-Lich. 4530, 4657, 4658. Galicia: 44, 1982, Barreno, Crespo \& Sancho, VAB-Lich. 8021.

\section{Usnea dasaea Stirt.}

Scott. Naturalist 6: 104 (1881).

Taxonomy. Usnea dasaea seems to be closely related to $U$. cormuta. It differs in having some branches at least with densely disposed spinulous fibrils on some parts of them, giving them a spinulous appearance, and in its chemistry (galbinic acid in the medulla, Clerc 1987a; Clerc \& Herrera-Campos 1997). This is the only European Usnea with galbinic acid.

Ecology and distribution. Usnea dasaea is mainly corticolous, but it also can occur on rocks (Clerc \& Herrera-Campos 1997). It has a worldwide distribution, except Antarctica and Australasia (Clerc \& Herrera-Campos 1997). Usnea dasaea has a southwestern distribution in Europe (Fig. 3). It was collected in Spain by E. Frey in the Catalonian cork-oak forests (see additional specimens examined, Clerc unpublished). It has also been reported from Italy, though the records require confirmation (Nimis 1993). This species is here reported as new for the Iberian Peninsula.

In this study, $U$. dasaea has only been collected in a Catalonian cork-oak forest (6). This site is located in an area with a subhumid ombroclimate and under coastal influence with frequent fog, and hosts other rare lichens (see Fos 1998). 


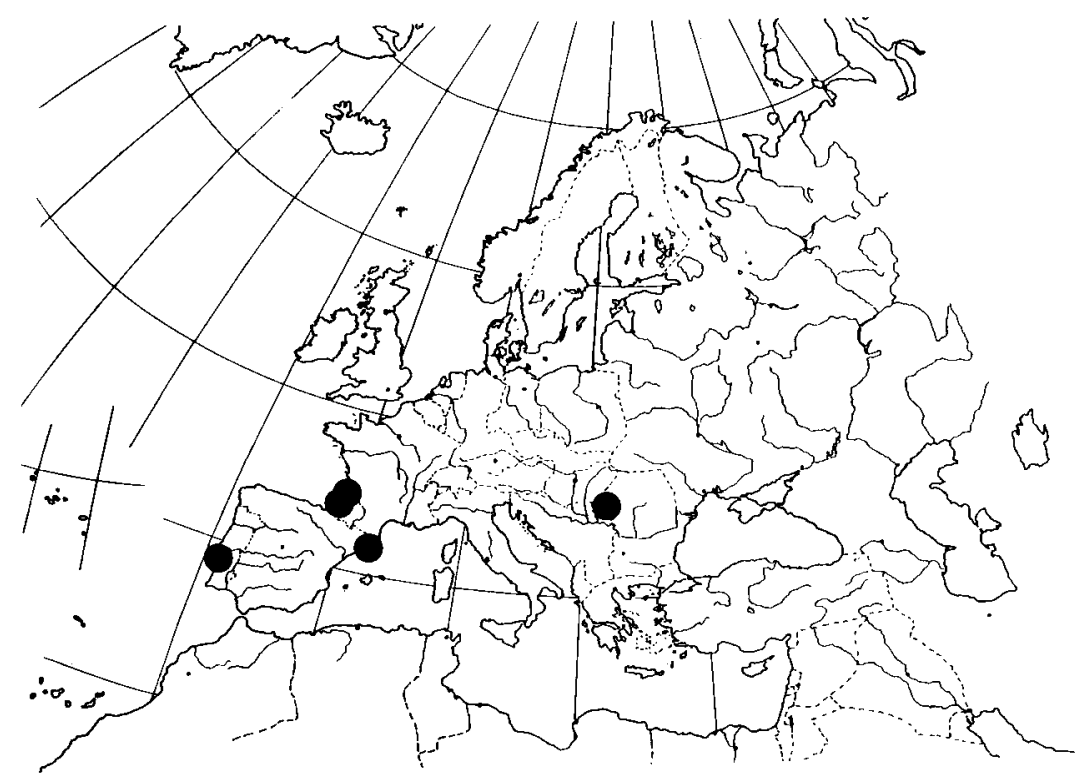

Fig. 3. Known European distribution of Usnea dasaea.

Specimens examined. Spain: Catalonia: 6, 1991, S. Fos, VAB-Lich. 4620.

Additional specimens examined. France: Landes: Gironde, 'Cestas', sur Ulmus, 1949, Plomb (MARS); Landes: Moliets entre Soustons et Léon, plantations de Quercus suber et Pinus maritima, 1950, Frey (BERN-Frey 14479) - Portugal: Estremadura: Serra de Sintra, parque da Pena, prox. dos Lagos, sôbre Fagus, 1944, C. Tavares (LISA).-Romania: an Buchen des Berges Ruszka im Banate, 1872, Lojka (W-holotype of $U$. dolosa Motyka).-Spain: Catalonia: Gerona, Massanès près de la station RENFE Empalme, colline en granit avec Quercetum suberis. Troncs et couronnes de Q. suber, NW, 120 m, 1950, Frey (BERN-Frey 14502); Gerona, Blanes-Tossa, Korkeichenwälder an der Strasse, auf Cistus monspeliensis, $80 \mathrm{~m}, 1934$, Frey (BERN-Frey 4308); Gerona, Bosche del Vilar bei Blanes, Quercetum suberis, 1951, Frey (BERN-Frey 17536).

\section{Usnea esperantiana P. Clerc}

Candollea 47: 2 (1992).

Taxonomy. This species, recently described by Clerc (1992), belongs to the $U$. fragilescens aggregate. Distinctive are the large and flat (sometimes slightly excavate) soralia at the tips of branches, without isidiomorphs, lateral branches distinctly constricted at their point of attachment, basal part concolorous with the main branches, and the presence of bourgeanic acid, beside salazinic acid.

Ecology and distribution. Corticolous, on a large variety of trees and bushes, especially on twigs and thin branches, always in areas with frequent fog (Clerc 1992). It has a distinct South European-Atlantic distribution, being known from the Canary Islands and from several localities in western Europe (Clerc 1992; Nimis 1993). Halonen et al. (1998) mention U. esperantiana for the first time for North America (W California and British Columbia). 
In this study, it was found in only two sites $(\mathbf{1 1}, \mathbf{2 2})$.

Specimens examined. Spain: Andalucia: 22, 1988, E. Barreno, VAB-Lich. 4635. Catalonia: 11, 1991, S. Fos, VAB-Lich. 4628.

\section{Usnea flammea Stirt.}

Scott. Naturalist 6: 104 (1881).

Taxonomy. Among the erect to subpendulous taxa, $U$. flammea differs from other sorediate species by its pale basal part with numerous annulations, its efflorescent, \pm protuberant and large soralia with numerous isidiomorphs and its chemical properties (norstictic, stictic acid aggr., \pm lobaric acids) (Clerc $1987 a$ ).

Ecology and distribution. This euoceanic species grows on all types of phorophytes including decorticated wood, and also on rocks and soil (James et al. 1992). It occurs in old, humid Atlantic forests, where the epiphytic lichen flora is dominated by oceanic species. Its distribution in Europe extends from the south western coast of Norway and the British Isles to Spain and Portugal (Clerc 1987a). It can be considered as rare in the Mediterranean region, although it is known from Yugoslavia, Greece, Italy and Portugal (Jones 1980; Clerc 1987a; Nimis 1993). In Spain, it has been reported only from the north (Bahillo 1989; Bahillo \& Carballal 1991; Etayo 1989, 1990; Etayo et al. 1991; Paz Bermúdez et al. 1995^).

In the areas studied, $U$. flammea seems to be very rare. It was found only in the luso-extremadurense cork-oak forests (Fig. 1D), at the same site (32) and in the same ecological position as $U$. cormuta (see note on this species).

Specimens examined. Spain: Extremadura: 32, 1992, S. Fos, VAB-Lich. 4657.

\section{Usnea fulvoreagens (Räsanen) Räsanen}

Lich. Fenn. Exs.: nr. 13 (1935).

Taxonomy. Usnea fulvoreagens belongs to the erect to subpendulous, tufted and sorediate Usnea with lateral branches that are not constricted at ramification points. In the past, this species has been confused with $U$. lapponica Vain. (syn. $U$. sorediifera auct.). Indeed, both taxa have the same kind of soralia that are deeply excavate, typically reaching the central axis and tearing off the adjacent cortex, and never producing isidiomorphs. However, these two taxa are very distinct and not closely related at all. Usnea fulvoreagens has a distinct isotomic-dichotomous branching pattern, cylindrical and tapering branches, a much thinner medulla (13-22\%), a distinct chemistry (see below) and a suboceanic distribution pattern. Usnea lapponica has a distinct sympodial branching pattern, branches that are cylindrical or \pm deformed and irregular, rarely tapering, a wider medulla (21-30\%), a different chemistry (salazinic or psoromic or caperatic acids) and a continental distribution (Clerc 1992). In Europe, two chemotypes seem to occur so far in $U$. fulvoreagens: one with norstictic acid, \pm stictic acid aggr., \pm diffractaic acid (Clerc 1987a, 1992; 
James et al. 1992). The second chemotype contains norstictic and squamatic acids (VAB-Lich. 4629, 4640), and has been detected in this work for the first time (Table 1; Fig. 2). The two strains can be found in the same site, as in Galaroza (34), and are morphologically indistinguishable. In North America, this species seems to be difficult to separate from $U$. glabrescens (Vain.) Vain. (Halonen et al. 1998).

Ecology and distribution. Corticolous, preferentially on branches of several phorophytes although more frequent on conifers. Acidophilous and anitrophilous (Wirth 1980), U. fulvoreagens is a suboceanic species, reported only a few times from Europe. It is known from Italy (Nimis 1993), the British Isles (James et al. 1992), Portugal (Jones 1980^), Madeira (Kalb \& Hafellner 1992*) and Spain (Bahillo \& Carballal 1991; Etayo 1990; Paz-Bermúdez et al. $1995^{\star}$ ). In the lberian Peninsula, it is present in the meso- and supramediterranean belts. In North America, it is known from British Columbia (Halonen et al. 1998) and from the Appalachians (Dey 1978).

Usnea fulvoreagens is present only in a few luso-extremadurense cork-oak forests, in particular those with an Atlantic influence ('MarianicoMonchiquense' subsector). In the shadier sites $(34,33)$, it is restricted to the branches, which can be densely covered, on peripheral trees, where it is associated with $U$. subfloridana and $U$. wasmuthii. When the canopy structure allows higher light penetration, it is also abundant on tree boles (31).

Specimens examined. Spain: Andalucia: 33, 1992, S. Fos, VAB-Lich. 4623; 34, 1992, S. Fos, VAB-Lich. 4606, 4631, 4640. Extremadura: 31, 1992, S. Fos, VAB-Lich. 4629. Galicia: 44, 1982, Barreno, Crespo E Sancho, VAB-Lich. 8022 .

\section{Usnea glabrata (Ach.) Vain.}

Ann. Acad. Sci. Fennicae A 6(7): 7 (1915).

Taxonomy. Usnea glabrata is one of the smallest Usnea species with an erect, tufted and sorediate thallus. Good descriptions are given in James et al. (1992), Myllys (1994) and Halonen et al. (1998). Like the species of the $U$. fragilescens aggr., lateral branches are distinctly constricted at ramification points and the cortex is glossy. Distinctive features are the conspicuous, mostly erumpent, convex-globular soralia, mostly situated at the tips of branches, the absence of isidiomorphs and true papillae, a thick and lax medulla, and the production of fumarprotocetraric acid as the main secondary substance.

Ecology and distribution. Corticolous, on numerous deciduous and coniferous trees. It occurs in open forests and may avoid stands with high atmospheric humidity (Myllys 1994). Its ecology is similar to that of the former species, though $U$. glabrata is rarely present in Lobarion communities. Usnea glabrata is widespread, but not frequent, in central and northern Europe, much rarer in the southern part of the continent, where it is mostly confined to mountainous forests (Clerc 1987c; Myllys 1994). Its global range extends to Asia, North America (Goward \& Ahti 1992; Halonen et al. 1998) and 
Macaronesia (Hafellner 1995). Goward \& Ahti (1992) suggested that its range is primarily low-boreal to temperate, perhaps primarily oceanic.

Usnea glabrata is present in the luso-extremadurense cork-oak forests, and is one of the few Usnea species collected in more continental 'Toledano-Tagano' territories. At the same site (24), U. subfloridana and, more frequently, $U$. wasmuthii also occur.

Specimens examined. Spain: Andalucia: 34, 1992, S. Fos, VAB-Lich. 4630. Extremadura: 24, 1990, S. Fos, VAB-Lich. 4632.

\section{Usnea hirta (L.) F. H. Wigg.}

Prim. FI. Hols.: 91 (1780).

Taxonomy. One of the most well known and commonly collected small tufted Usnea species, the typical features of which are the pale basal part, the absence of true papillae, the \pm deformed and foveolated main branches, the minute and numerous soralia covered with isidiomorphs and the chemistry ( \pm norstictic acid, \pm fatty acids of the murolic acid complex) (Clerc 1987a; James et al. 1992; Halonen \& Puolasmaa 1995; Halonen et al. 1998).

Ecology and distribution. Corticolous, especially on acid bark, and lignicolous. Usnea hirta grows mostly on the branches of conifers, especially on Pinus, and less frequently on deciduous trees. Photophilous (Halonen et al. 1991), it can often be found in open sites, where it usually forms dense stands on trees, whereas it is rare in shady and moist sites (Halonen \& Puolasmaa 1995). It is a strongly continental species that occurs within the Usneion barbatae Ochsner 1928 and Pseudevernietum furfuraceae (Hilitzer) Ochsner 1928 communities, in open pine forests of the supra- and oromediterranean belts (Sabino-Pino sylvestris sigmetum); in Eurosiberian vegetation belts, it is distributed from the lower montane to the subalpine belts. It can frequently be found occurring within nitrophilous Xanthorion communities (Nimis 1981). It is relatively resistant to air pollution (Wirth 1980; Kauppi \& Halonen 1992). Usnea hirta is a species of worldwide distribution (Clerc 1997; Halonen et al. 1998). In Europe, it has been reported from boreal areas to Mediterranean mountains (Wirth 1980; Clauzade \& Roux 1985; Nimis 1993; Halonen \& Pulasmaa 1995). Widespread in the Iberian Peninsula, especially in continental areas.

Due to its preference for climatically continental areas, $U$. hirta is seldom found in cork-oak forests. This species is present in those sites where the climate is rather more continental and it is quite abundant in the supramediterranean cork-oak forest of Burgos (45). It also occurs in Catalonia, but it is restricted to the highest elevations sites (10), and at North of Huelva (33).

Specimens examined. Spain: Andalucia: 33, 1992, S. Fos, VAB-Lich. 4615. Castilla-León: 45, 1995, P. Pérez-Rovira $\mathcal{G} G$. Renobales, VAB-Lich. 4662. Catalonia: 10, 1991, S. Fos, VAB-Lich. 4622 . 


\section{Usnea mutabilis Stirt.}

Scott. Naturalist 6: 107 (1881).

U. marocana Motyka (Clerc 1994, 1997)

Taxonomy. A detailed description of this mainly North American species is given in Clerc (1994). Usnea mutabilis is closely related to $U$. hirta but has a wine-red pigment in the medulla, a thicker cortex $(6 \cdot 5-10.5 \%)$ and a more compact medulla (Clerc 1994). Chemically, it produces the same fatty acids of the murolic acid complex as $U$. hirta. Both species are the only Usnea in the Northern Hemisphere that are known to produce this type of substance.

Ecology and distribution. Mainly corticolous, rarely saxicolous (Clerc \& Herrera-Campos 1997), U. mutabilis shows a typical disjunctive distribution in the four continents of the Northern Hemisphere (see distribution map in Clerc 1994). In Europe and North Africa it is only present in the Mediterranean region: Morocco, Iberian Peninsula, France and Italy (Werner 1975; GómezBolea 1985; Boqueras \& Gómez-Bolea 1986, 1987; Abbasi-Maaf \& Roux 1986; Clauzade \& Roux 1989; Nimis 1993; Clerc 1994).

In our survey, $U$. mutabilis was found only in an especially humid site $(6$, see comments for $U$. dasaea) close to the forests of $Q$. canariensis. It colonises the upper part of the trunks and the exposed branches, where it is accompanied by such species as $U$. dasaea, $U$. rubicunda, Parmelia hypoleucina, $P$. caperata Gómez-Bolea (1985) and Boqueras \& Gómez-Bolea $(1986,1987)$ found it in several sites of Catalonia within the Usneetum marocanae Boqueras \& GómezBolea 1987 synusia. They described this union from the shady areas of the littoral mountains and pre-littoral depression, where fog episodes are frequent. In the cork-oak forest of Cádiz, U. mutabilis has been reported by Werner (1975) between Algeciras and Gibraltar.

Specimens examined. Spain: Catalonia: 6, 1991, S. Fos, VAB-Lich. 8462.

\section{Usnea rubicunda Stirt.}

Scott. Naturalist 6: 102 (1881).

Taxonomy. This is the only Usnea known to occur in Europe that has a red cortical pigment. This pigment is sometimes difficult to see and one should especially look at the basal part. Necrotic thalli of other species collected on soil might be reddish and thus confused with $U$. rubicunda. Other typical features are the punctiform soralia covered with isidiomorphs, the non-blackened basal part, the cylindrical and tapering branches.

Ecology and distribution. Corticolous, on several deciduous trees and, rarely, on conifers, mostly on branches; it seldom grows on siliceous rocks (Swinscow \& Krog 1979; Rowe \& Egea 1986). Photophilous and hygrophilous, it is common in areas with an oceanic climate, in ancient woodlands or on isolated trees near waysides and boundaries. Usnea rubicunda has a cosmopolitan distribution in many suboceanic and oceanic temperate and tropical regions and has been recorded from both Hemispheres. In Europe, it is the most 
common species in the western part of the continent, extending west to Macaronesia, Central Europe and the Atlantic-Mediterranean areas (James 1979; Wirth 1980; Hafellner 1995). In the Iberian Peninsula, it has been frequently reported from coastal or oceanic areas.

Usnea rubicunda is the most common and abundant Usnea in the areas studied within the climatic conditions mentioned above: cork-oak forests of Catalonia and in Oleo-Quercetum suberis and Myrto-Quercetum suberis forest from Cádiz, Huelva and Portugal. It usually grows on exposed branches, which become abundantly covered, though it is not rare on boles. It also occurs in other areas, such as luso-extremadurense forests associated with hyperhumid ombroclimate (40).

Specimens examined. Spain: Andalucia: 18, 1992, S. Fos, VAB-Lich. 3535; 19, 1992, S. Fos, VAB-Lich. 3565; 1988, E. Barreno, VAB-Lich. 9315; 20, 1992, S. Fos, VAB-Lich. 3455; 21, 1992, S. Fos, VAB-Lich. 3746, 4981; 22, 1992, S. Fos, VAB-Lich. 3768; 1988, E. Barreno, VAB-Lich. 4533, 8083; 23, 1992, S. Fos, VAB-Lich. 3487; 36, 1995, S. Fos, VAB-Lich. 4681. Catalonia: 1, 1991, S. Fos, VAB-Lich. 9120; 2, 1994, S. Fos, VAB-Lich. 4543; 3, 1991, S. Fos, VAB-Lich. 3316; 4, 1991, S. Fos, VAB-Lich. 8068; 5, 1991, S. Fos, VAB-Lich. 4542; 6, 1991, $S$. Fos, VAB-Lich. 3890, 8463; 7, 1991, S. Fos, VAB-Lich. 3387; 9, 1991, S. Fos, VAB-Lich. 4540; 10, 1991, S. Fos, VAB-Lich. 9448; 11, 1991, S. Fos, VAB-Lich. 8045.-Portugal: Algarve: 38, 1990, E. Barreno $\mathcal{E} S$. Fos, VAB-Lich. 3023; 40, 1990, E. Barreno $\mathcal{E} S$. Fos, VAB-Lich. 3073; Ribatejo: 37, 1990, E. Barreno \& S. Fos, VAB-Lich. 3017.

\section{Usnea subcornuta Stirt.}

Scott. Naturalist 6: 107 (1881).

Taxonomy. This is a rare and poorly known species. Hawksworth et al. (1980) considered it as a synonym of $U$. cormuta. Based on observations made on the type material, Clerc (1987a) indicated that $U$. subcornuta is a distinct species, characterised by the presence of an orangish pinkish red pigment under the cortex (subcortical) in the medulla. Unfortunately the original material consists of two small and badly developed thalli and it was not easy to understand this species on this basis. More recent collections (see Fig. 4), however, now give us a better idea about what this species really is. Morphologically, $U$. subcornuta is very similar to $U$. flammea (see under this species), differing only by the presence of the subcortical pigment and of a glossy cortex. Lateral branches are not constricted at attachment points. Chemically the type specimens have several yellow pigments whereas the three collections from Morocco, Portugal and Russia have the stictic acid aggr. and norstictic acid.

Ecology and distribution. A very rare corticolous species. Known only from a few localities in Europe (Fig. 4) where it seems to have a western Mediterranean-Macaronesian type of distribution with 'microclimatic' outposts, as for instance in the western Caucasus where other Usnea species with a similar type of distribution (U. hesperina and $U$. mutabilis) have been found (Clerc 1991).

The specimen referred to in this study was collected in a Portuguese cork-oak forest within Oleo-Quercetum suberis (37). It occurs on peripheral and 


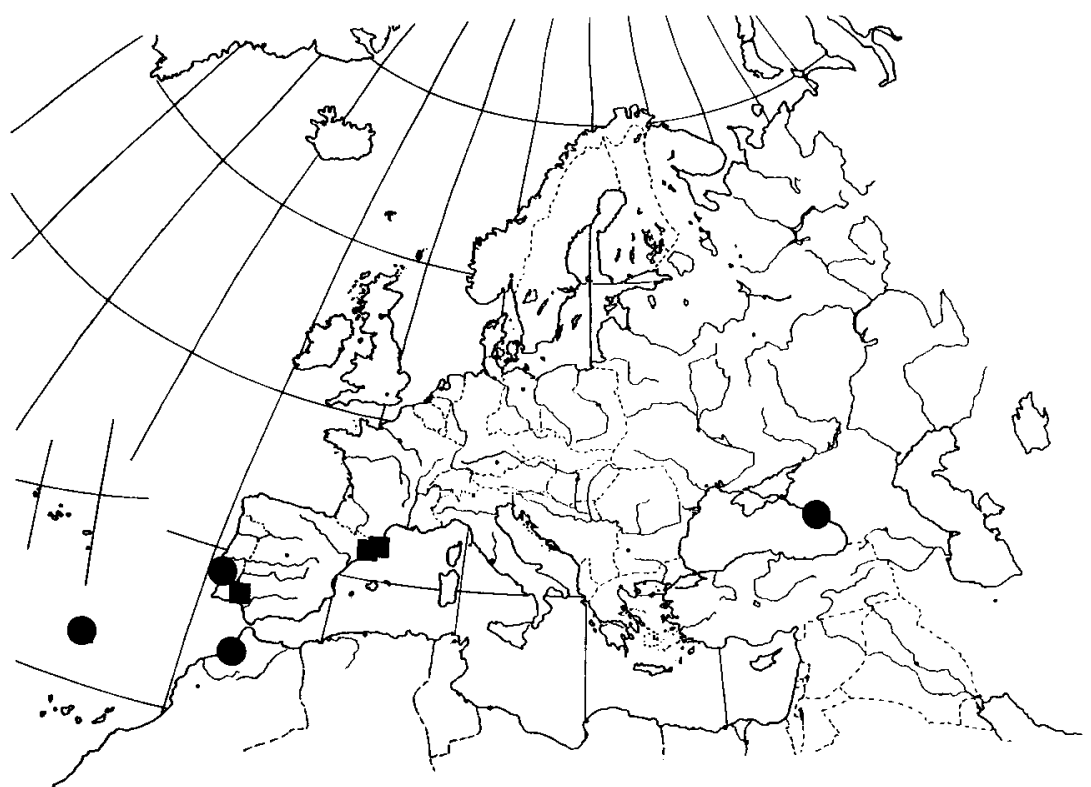

FIG. 4. Known world distribution of Usnea subcornuta. Studied specimens (O) and literature records (ם).

exposed branches of young trees with very open crowns, accompanied by U. rubicunda and Parmelia hypoleucina.

Specimens examined. Portugal: Ribatejo: 37, 1990, E. Barreno \& S. Fos, VAB-Lich 4654.

Additional specimens examined. Portugal: Madeira: near Funchal, Payne (BM-holotype).Morocco: Ad corticem Quercus suberis in Mamora silva prope Rabat, 31 xii 1933, leg. ? (unreadable) (BERN-Frey 3881).-Russia: Caucasus occidentalis: distr. Khosta, in valle fluminis Khosta, loco 'Navalishenskoie uscelie' dicto, 200-300 m, 1980, V. Vasak, GZU 130-83.

\section{Usnea subfloridana Stirt.}

Scott. Naturalist 6: 294 (1882).

Taxonomy. Descriptions of this species can be found in James et al. (1992) and in Halonen et al. (1998). The following combination of characters is diagnostic: thallus erect to subpendulous, basal part jet black pigmented; small, plane and numerous soralia, covered with isidiomorphs; isotomicdichotomous branching; branches terete, tapering, not constricted at attachment points; medulla dense to compact; thamnolic, \pm hypothamnolic acid \pm squamatic, \pm alectorialic acids or squamatic acid alone in the medulla. Most specimens collected in this study have thamnolic \pm squamatic acids (Table 1; Fig. 2). These two chemotypes are morphologically indistinguishable and they do not seem to show any ecological difference. Both are usually present in the same sampling plot and often on the same tree.

Specimens belonging to a third chemotype (norstictic and connorstictic acids) (Fig. 2) have been collected in this study (VAB-Lich. 4603, 4665). 
They correspond to Usnea subfloridana subsp. praetervisa (Asahina) P. Clerc comb. nov. [Basionym: Usnea comosa subsp. praetervisa Asahina, Lichens of Japan III. Genus Usnea: 95 (1956)]. This taxon is known to occur in North America (Clerc unpublished), Europe and Eastern Asia (Asahina 1956). More work is needed to assess its status.

Ecology and distribution. Corticolous, occurring on a great variety of phorophytes. Photophilous (Etayo 1989), it prefers well-lit open localities where it grows mostly on branches. It is present in Atlantic and Mediterranean areas, extending to the upper mesomediterranean and lower supramediterranean belts with subhumid to hyperhumid ombroclimates (Marcos Laso 1985). However, in Italy, it is one of the few Usnea species that are also present at low altitudes, and sometimes even near urban settlements, in areas with low air pollution (Nimis 1993). Usnea subfloridana is rather common throughout Europe (Clerc 1987a, c). In Spain, $U$. subfloridana has been reported frequently, especially from the northern Iberian Peninsula, and seldom in typical Mediterranean vegetation.

In our survey, $U$. subfloridana seems to have its optimum in lusoextremadurense cork-oak forests. It is almost exclusive to these territories and it is present in numerous sites, where it can locally reach significant development and biomass. It usually grows on branches, often forming dense stands, but in open woodlands it is one of the most frequent Usnea species on trunks as well. Outside this province, it has been found only in Málaga (17) and Burgos (45). The absence from Cádiz and Catalonia seems to indicate preference for rather continental areas.

Specimens examined. Spain: Andalucia: 17, 1993, E. Calvo, VAB-Lich. 4665; 33, 1992, S. Fos, VAB-Lich. 4603; 34, 1992, S. Fos, VAB-Lich. 4601, 4605, 4625, 4652; 35, 1992, S. Fos, VAB-Lich. 4636, 4653. Castilla-León: 45, 1995, P. Pérez-Rovira $\mathcal{E}$ G. Renobales, VAB-Lich. 4661. Extremadura: 24, 1990, S. Fos, VAB-Lich. 4604; 29, 1993, S. Fos E E. Barreno, VAB-Lich. 4647; 30, 1993, E. Barreno $\mathcal{E} S$. Fos, VAB-Lich. 4648, 4626.

\section{Usnea subscabrosa Motyka}

Lich. Gen. Usnea Stud. Monogr., Pars Syst 2: 313 (1937).

Taxonomy. For a detailed description, see Clerc (1992), James et al. (1992), and Herrera-Campos et al. (1998). The main diagnostic characters are the thick and vitreous cortex, minute soralia with or without isidiomorphs, pale trunk often with a reddish hue, and chemistry with protocetraric acid as the main substance (Clerc \& Herrera-Campos 1997) (Table 1; Fig. 2).

Ecology and distribution. Both corticolous and saxicolous, moderately acidophilous, anitrophilous and moderately toxitolerant (Wirth 1980), $U$. subscabrosa displays a south-western European-Macaronesian-NE American disjunction (Clerc 1992; Esslinger \& Egan 1995; Clerc \& Herrera-Campos 1997). In Europe, it has been reported from several localities, from Portugal and the British Isles to Yugoslavia; it is known also from South America (Clerc 1997). In the Iberian Peninsula, it has been reported by numerous authors. 
In our survey, $U$. subscabrosa is especially well represented in the cork-oak forests of Cádiz, both in Myrto-Quercetum suberis and in Teucrio-Quercetum suberis stands. It grows preferentially on branches and frequently colonises well-lit trunks. In the Portuguese cork-oak forests it is present in all vegetation series, being here the most common Usnea, although $U$. rubicunda is more abundant in more oceanic sites. In other localities, such as Malavella (7), in Catalonia, and Zahinos (32), in the Mariánico-Monchiquense sector (Luso-extremadurense province), $U$. subscabrosa is also quite abundant. The specimen reported from Catalonia as Usnea mollis Stirt. (Boqueras \& Gómez-Bolea 1986:63) also corresponds to U. subscabrosa.

Specimens examined. Spain: Andalucia: 18, 1992, S. Fos, VAB-Lich. 4608; 21, 1992, S. Fos, VAB-Lich. 4613; 22, 1992, S. Fos, VAB-Lich. 4621; 1988, E. Barreno, VAB-Lich. 4611; 23, 1992, S. Fos, VAB-Lich. 4645; 34, 1992, S. Fos, VAB-Lich. 4630. Catalonia: 7, 1991, S. Fos, VAB-Lich. 4609, 4616, 4617, 4624. Extremadura: 32, 1992, S. Fos, VAB-Lich. 4610, 4659, 4660.-Portugal: Algarve: 38, 1990, E. Barreno $\mathcal{E} S$. Fos, VAB-Lich. 4655, 4656; 40, 1990, E. Barreno $\mathcal{E} S$. Fos, VAB-Lich. 4614; 41, 1990, E. Barreno $\mathcal{E} S$. Fos, VAB-Lich. 4668. Alto Alentejo: 42, 1990, E. Barreno $\mathcal{E}^{\circ}$ S. Fos, VAB-Lich. 4651. Baixo Alenteio: 39, 1990, E. Barreno \& S. Fos, VAB-Lich. 4612, 4607; Ribatejo: 37, 1990, E. Barreno E S. Fos, VAB-Lich. 4666, 4667.

Additional specimens examined. Spain: Catalonia: Girona, La Selva, Llagostera-Caldes de Malavella road, km 17, 31TDG82, $120 \mathrm{~m}, 1984, A$. Gómez-Bolea, BCC-I ich. 3121.

\section{Usnea substerilis Motyka}

Wyd. Muz. Slask. Katowic. 3 (2): 24 (1930).

Taxonomy. A modern concept of this species is given in Halonen et al. (1998). Usnea substerilis is closely related to U. lapponica, from which it differs in its soralia that are not deeply excavate but superficial, not tearing off the adjacent cortex, usually with isidiomorphs when young. The thallus is usually short, erect-tufted; branches are circular to \pm deformed, swollen, irregular to more rarely tapering. Chemically, it produces salazinic \pm barbatic acid in the medulla (Table 1; Fig. 2).

Ecology and distribution. This corticolous taxon occurs in areas with \pm continental climate, often together with $U$. lapponica and $U$. scabrata. It is one of the most frequent Usnea from low altitudes to mountainous areas in the Alps. It is also frequent in the boreal zone of Europe, North America and Russia. In Spain, it has been reported by Sarrión et al. (1993) from Sierra Madrona Mountain (Ciudad Real, C Spain). (43).

It is the only Usnea species found in the cork-oak forest of Haza del Lino

Specimens examined. Spain: Andalucia: 43, 1991, S. Fos, VAB-Lich. 4602.

\section{Usnea wasmuthii Räsänen}

Flecht. Estlands I., Suom. Tidenknd. Taim. 34 (4): 17-19 (1931).

Taxonomy. Good descriptions can be found in Clerc (1992) and James et al. (1992). Usnea wasmuthii is closely related to $U$. subfloridana (see 
above) but soralia are slightly excavate, ulcer-like, longitudinally stretched (mature soralia), with isidiomorphs only in young soralia and the basal blackened part of thallus with faint, transverse and longitudinal cracking $(\times 50)$ forming a fine rimose areolation. Chemically, $U$. wasmuthii differs from $U$. subfloridana in having salazinic \pm barbatic acids or barbatic acid alone in the medulla. Most specimens collected in our survey contain both salazinic and barbatic acid (Table 1; Fig. 2). However, several specimens have been found that produce thamnolic \pm squamatic acids, the typical substances for $U$. subfloridana. Thus, what has been considered as a possible 'hybrid' (Clerc 1992) might well be considered as a rare chemotype of $U$. wasmuthii. Additionally, we have found a new chemotype with barbatic and psoromic acid (Fig. 2). These various chemotypes have been found not only in the same sampling plot, but also, side by side in the same herbarium packet.

Ecology and distribution. Corticolous, on several phorophytes. This is an Eurasian oceanic-suboceanic species, the European distribution of which very much resembles that of $U$. florida (Clerc 1984a, 1992). It is widespread but not frequent in the whole of Europe (Clerc 1987c). In the Iberian Peninsula it is known only from Eurosiberian areas with a humid-hyperhumid ombroclimate (Bahillo \& Carballal 1991; Etayo 1989) and Mediterranean territories with Atlantic influence (Sarrión et al. 1993; Vázquez \& Burgaz 1996*; Aragón \& Martínez 1997*; Aragón \& Rico 1997*; Seaward \& Arvidsson 1997; Martinez \& Sarrión 1998).

Like $U$. subfloridana, $U$. wasmuthii seems to have its optimum in the southwestern part of the Iberian Peninsula, although it could not be found in the Portuguese cork-oak forests. It seems to be absent from areas with a coastal influence. In the luso-extremadurense province, it occurs with unequal frequency in dense, humid and shady stands, where it is especially abundant. It is also found in grassy woodlands exposed to strong sunshine and desiccating winds, although its presence is rather occasional in this environment. Curiously, it is the only species of Usnea found in the cork-oak forests of Valencia-Castellón.

Specimens examined. Salazinic and barbatic acids: Spain: Andalucia: 16, 1993, Barreno, Calatayud Sanz \& Nash, VAB-Lich. 4643; 34, 1992, S. Fos, VAB-Lich. 4601, 4639; Comunidad Valenciana: 12, 1992, M. A. Codoñer \& S. Fos, VAB-Lich. 4989; 13, 1992, M. A. Codoñer $\mathcal{E} S$. Fos, VAB-Lich. 4990; 14, 1992, E. Calvo $\mathcal{F} S$. Fos, VAB-Lich. 4991; 15, 1992, S. Fos, VAB-Lich. 4988. Extremadura: 24, 1990, S. Fos, VAB-Lich. 4618; 25, 1990, $S$. Fos, VAB-Lich. 4644; 26, 1990, S. Fos, VAB-Lich. 4634; 27, 1990, S. Fos, VAB-Lich. 4619, 4637; 28, 1990, S. Fos, VAB-Lich. 4638; 29, 1993, S. Fos $\mathcal{F}$ E. Barreno, VAB-Lich. 4646; 30 , 1993, E. Barreno \& $S$. Fos, VAB-Lich. 4626, 4627, 4641, 4649; 31, 1992, S. Fos, VAB-Lich. 4663 .

Thamnolic \pm squamatic acids: Spain: Andalucia: 34, 1992, S. Fos, VAB-Lich. 4630. Extremadura: 29, 1993, S. Fos $\mathcal{E}$ E. Barreno, VAB-Lich. 4650; 30, 1993, E. Barreno $\mathcal{E} S$. Fos, VAB-Lich. 4627, 4649; 31, 1992, S. Fos, VAB-Lich. 4642.

Barbatic and psoromic acids: Spain: Extremadura: 24, 1990, S. Fos, VAB-Lich. 4618.

The first author is indebted to Dr E. Barreno for funding. Additionally, we wish to thank V. I. Deltoro for polishing the English version. 


\section{REFERENCES}

Abbassi Maaf, L. \& Roux, C. (1986) Les peuplements lichéniques corticoles de la Chênaie verte: ètude comparée de la gardiole de Rians et de L'îlle de Port-Cros (Var). Bulletin de la Société Linnéenne de Provence 38: 189-245.

Aragón, G. \& Martinez, I. (1997) Contribución al conocimiento de los líquenes epifiticos de los Montes de Toledo (Toledo, España). Cryptogamie, Bryologie et Lichénologie 18: 63-75.

Aragón, G. \& Rico, V. J. (1997) Los macrolíquenes del macizo del Calar del Mundo (Albacete) y de la Sierra de Segura (Jaén, España). Lazaroa 18: 45-93.

Asahina, Y. (1956) Lichens of fapan. Vol. III. Genus Usnea. Tokyo: Research Institute for Natural Resources Shinjuku.

Bahillo, L. (1989) Vegetación y Flora de los Liquenes Epifitos de la Cuenca del río Oitaven (Pontevedra). Doctoral Thesis, University of Santiago, Spain.

Bahillo, L. \& Carballal, R. (1991) Fragmenta Chorologica Occidentalia, Lichenes, 3467-3499. Anales del Jardín Botánico del Madrid 49: 113-115.

Boqueras, M. \& Gómez-Bolea, A. (1986) Líquens epífits, i els seus fongs paràsits, observats sobre Quercus suber, a Catalunya. Folia Botanica Miscelanea 5: 49-69.

Boqueras, M. \& Gómez-Bolea, A. (1987) La vegetación liquénica epifítica de Quercus suber L. en Catalunya (España). Actas del VI Simposio Nacional de Botánica Criptogámica: 371-382.

Clauzade, G. \& Roux, C. (1985) Likenoj de Okcidenta Europo. Ilustrita determinlibro. Bulletin de la Société Botanique Centre-Ouest, Nouvelle série-Numéro Spécial 7: 1-893.

Clauzade, G. \& Roux, C. (1989) Likenoj de Okcidenta Europo. Ilustrita determinlibro. Suplemento 3a. Bulletin de la Société Linnéenne de Provence 40: 73-110.

Clerc, P. (1984a) Contribution à la révision de la systématique des Usnées (Ascomycotina, Usnea) d'Europe I. Usnea florida (L.) Wigg. emend. Clerc. Cryptogamie, Bryologie et Lichénologie 5: $330-360$.

Clerc, P. (1984b) Usnea wirthii-a new species of lichens from Europe and North Africa. Saussurea 15: 33-36.

Clerc, P. (1987a) Systematics of the Usnea fragilescens aggregate and its distribution in Scandinavia. Nordic Fournal of Botany 7: 479-495.

Clerc, P. (1987b) On the morphology of soralia in the genus Usnea. Bibliotheca Lichenologica 25: 99-107.

Clerc, P. (1987c) Usnea. In The Lichens and Lichenicolous Fungi of Sardinia (Italy) (P. L. Nimis \& J. Poelt, eds). Studia Geobotanica 7: 237-239.

Clerc, P. (1991) Usnea madeirensis Mot (ascomycète lichènisé): une espèce méconnue de l'Europe el de l'Amérique du Nord. Candollea 46: 427-438.

Clerc, P. (1992) Some new or interesting species of the genus Usnea (Lichenized Ascomycetes) in the British Isles. Candollea 47: 513-526.

Clerc, P. (1994) Comment Usnea mutabilis Stirton, une espèce nord-américaine, se cache en Europe sous le nom d'Usnea marocana Motyka. Une contribution à la systématique du genre Usnea (ascomycètes lichénisés). Bulletin de la Société Linnéenne de Provence 45: 309-316.

Clerc, P. (1997) Notes on the genus Usnea Dill. ex Adanson. Lichenologist 29: 209-215.

Clerc, P. (1998) Species concepts in the genus Usnea (Lichenized Ascomycetes). Lichenologist 30: 321-340.

Clerc, P. \& Herrera-Campos, M. A. (1997) Saxicolous species of Usnea Subgenus Usnea (Lichenized Ascomycetes) in North America. Bryologist 100: 281-301.

Culberson, C. F. (1972) Improved conditions and new data for the identification of lichen products by a standard thin-layer chromatographic method. Foumal of Chromatography 72: 125-133.

Culberson, C. F. (1974) Conditions for use of Merck silica-gel 60F 254 Plates in the standardized thin layer chromatographic technique for lichen products. Joumal of Chromatography 97: 107-108.

Culberson, C. F. \& Ammann, K. (1979) Standardmethode zur Dünnschichtchromatographie von Flechtensubstanzen. Herzogia 5: 1-24.

Culberson, C. F. \& Kristinsson, H. D. (1970) A standardized method for the identification of lichen products. Fournal of Chromatography 46: 85-93.

Degelius, G. (1935) Das ozeanische Element der Strauch- und Laubflechtenflora von Skandinavien. Acta Phytogeographica Suecica 7: 1-411. 
Dey, J. P. (1978) Fruticose and foliose lichens of the high-mountain areas of the southern Appalachians. Bryologist 81: 1-93.

Esslinger, T. L. \& Egan, R. S. (1995) A sixth checklist of the lichen-forming, lichenicolous, and allied fungi of the continental United States and Canada. Bryologist 98: 467-549.

Etayo, J. (1989) Liquenes Epifitos del Norte de Navarra. Doctoral Thesis, University of Navarra, Spain.

Etayo, J. (1990) Ensayo de la vegetación liquénica epífita del Norte de Navarra. Principe de Viana (Suplemento de Ciencias) 10: 39-71.

Etayo, J., López de Silanes, M. E. \& Bahillo, L. (1991) Contribución a la flora liquénica de Galicia central-Tras os Montes, I. Nova Acta Cientifica Compostelana (Bioloxia) 2: 31-39.

Fos, S. (1998) Liquenes Epifitos de los Alcomocales Libéricos. Correlaciones Bioclimáticas, Anatómicas y Densiméticas con el Corcho de Reproducción. Guineana 4. Bilbao: Servicio Editorial de la E.H.U.

Gómez-Bolea, A. (1985) Liquenes Epifitos de Cataluña. Barcelona: Comitè de Publicacions, Intercanvi cientific i Extensió Universitaria. Universitat de Barcelona.

Goward, T. \& Ahti, T. (1992) Macrolichens and their zonal distribution in Wells Gray Provincial Park and its vicinity, British Columbia, Canada. Acta Botanica Fennica 147: 1-60.

Hafellner, J. (1995) A new check-list of lichens and lichenicolous fungi of insular Laurimacaronesia including a lichenological bibliography for the area. Fritschiana 5: 1-132.

Halonen, P. (1997) The lichen genus Usnea in eastern Fennoscandia. II. Usnea longissima. Graphis scripta 8: 51-56.

Halonen, P. \& Poulasmaa, A. (1995) The lichen genus Usnea in eastern Fennoscandia. I. Usnea hirta. Annales Botanici Fennici 32: 127-135.

Halonen, P., Hyvärinen, M. \& Kauppi, M. (1991) The epiphytic lichen flora on conifers in relation to climate in the Finnish Middle Boreal Subzone. Lichenologist 23: 61-72.

Halonen, P., Clerc, P., Goward, T., Brodo, I. M. \& Wulf, K. (1998) Synopsis of the genus Usnea (Lichenized Ascomycetes) in British Columbia, Canada. Bryologist 101: 36-60.

Hawksworth, D. L. James, P. W. \& Coppins, B. J. (1980) Check-list of British lichen-forming, lichenicolous and allied fungi. Lichenologist 12: 1-115.

Herrera-Campos, M. A., Clerc, P. \& Nash III, T. H. (1998) Pendulous species of Usnea from the temperate forest in Mexico. Bryologist 101: 303-329.

James, P. W. (1979) Notes on Usnea rubiginea and U. mubicunda. Lichenologist 11: 322-323.

James, P. W., Clerc, P. \& Purvis, O. W. (1992) Usnea Hill. (1753). In The Lichen Flora of Great Britain and Ireland. (O. W. Purvis \& B. J. Coppins, D. L. Hawksworth, P. W. James \& D. M. Moore, eds): 620-629. London: Natural History Museum Publications.

Jones, M. P. (1980) Epiphytic macrolichens of the Algarve, Portugal. Lichenologist 12: 253-275.

Jørgensen, P. M. (1996) The oceanic element in the Scandinavian lichen flora revisited. Symbolae Botanicae Upsaliensis 31: 297-317.

Kalb, K \& Hafellner, J. (1992) Bemerkenswerte Flechten und lichenicole Pilze von der Insel Madeira. Herzogia 9: 45-102.

Kauppi, M. \& Halonen, P. (1992) Lichens as indicators of air pollution in Oulu, northern Finland. Annales Botanici Fennici 29: 1-9.

Marcos Laso, B. (1985) Flora y Vegetación Liquénica Epifitica de las Sierras Meridionales Salmantinas. Doctoral Thesis, University of Salamanca, Spain.

Martínez, I. \& Sarrión, G. (1998) Líquenes epifíticos de Olea europaea L. en la Sierra de Santa Olalla (NW-Cáceres, España). Botanica Complutensis 22: 75-81.

Montoya, J. M. (1988) Los Alcomocales. 2nd Edn. Madrid: Ministerio de Agricultura, Pesca y Alimentación.

Myllys, L. (1994) Usnea glabrata (lichenized Ascomycotina) in East Fennoscandia. Acta Botanica Fennica 150: 125-130.

Nimis, P. L. (1981) Epiphytic lichen vegetation in the Lumiei-Valley (Carnian Alps). Gortania 3: 123-142.

Nimis, P. L. (1993) The Lichens of Italy. An Annotated Catalogue. Monografia XII. Torino: Museo Regionale di Scienze Naturali.

Paz Bermúdez, G., Carballal, R. \& López de Silanes, M. E. (1995) Líquenes epífitos sobre Betula L. en Galicia (España). Cryptogamie, Bryologie et Lichénologie 16: 61-70.

Rivas-Martinez, S. (1987) Memoria del Mapa de Series de Vegetación 1:400.000. Madrid: Ministerio de Agricultura, Pescay Alimentación. 
Rivas-Martínez, S., Lousa, M., Diaz, T. E., Fernández González, F. \& Costa, J. C. (1990) La vegetación del Sur de Portugal (Sado, Alentejo y Algarve). Itinera Geobotanica 3: 5-126.

Rowe, J. G. \& Egea, J. M. (1986) Liquenes silicícolas de las sierras costeras occidentales de la comarca de Algeciras (Cádiz, España). Acta Botánica Malacitana 11: 55-74.

Sarrión, F. J., Martínez, I. \& Burgaz, A. R. (1993) Líquenes epífitos de Sierra Madrona (Ciudad Real, España). Cryptogamie, Bryologie et Lichénologie 14: 389-400.

Seaward, M. R. D. \& Arvidsson, L. (1997) Additions to the lichen flora of Málaga Province, S. Spain. Nova Hedwigia 64: 129-135.

Swinscow, T. D. V. \& Krog, H. (1979) The fruticose species of Usnea subgenus Usnea in East Africa. Lichenologist 11: 207-252.

Terrón, A., Llamas, B. \& Penas, A. (1992) Aportaciones al estudio de algunas comunidades brioliquénicas de la provincia de León. Lazaroa 13: 23-31.

Vázquez, S. \& Burgaz, A. R. (1996) Flora liquénica de la provincia de Toledo (Toledo, España). Botanica Complutensis 21: 39-50.

Werner, R. G. (1975) Etude écologique et phytogéographique sur les lichens de l'Espagne méridionale. Révue Bryologique et Lichénologique 41: 55-82.

White, F. J. \& James, P. W. (1985) A new guide to microchemical techniques for the identification of lichen substances. British Lichen Society Bulletin 57(Suppl.): 1-41.

Wirth, V. (1980) Flechtenflora. Ökologische Kennzeichnung und Bestimmung der Flechten Südwestdeutschlands und Angrenzender Gebiete. Stuttgart: Verlag Eugen Ulmer.

Accepted for publication 19 fune 1999 